\title{
Integration of Scientific Article Writing in the Animal Systematics Course to Train Scientific Literacy
}

\author{
Ulfi Faizah \\ Department of Biology, Faculty of \\ Mathematics and Natural Sciences \\ Universitas Negeri Surabaya \\ Surabaya, Indonesia \\ ulfifaizah@unesa.ac.id
}

\author{
Reni Ambarwati \\ Department of Biology, Faculty of \\ Mathematics and Natural Sciences \\ Universitas Negeri Surabaya \\ Surabaya, Indonesia \\ reniambarwati@unesa.ac.id
}

\author{
Dwi Anggorowati Rahayu \\ Department of Biology, Faculty of \\ Mathematics and Natural Sciences \\ Universitas Negeri Surabaya \\ Surabaya, Indonesia \\ dwirahayu@unesa.ac.id
}

\begin{abstract}
One of the $21^{\text {st }}$ century skills needed by students is scientific literacy skill. Students who take Animal Systematics courses which are needed to train in scientific literacy skills through scientific writing activities. This study aimed to describe the integration of writing scientific articles in systematic courses of animals. The purpose of this research was to train scientific literacy in biology students. The indicators of scientific literacy that are expected of students that they could deal with ideas, shared their thoughts, enriched their understanding, and could solve their problems. To realize the indicators, a series of scientific writing activities were carried out consisting of making research proposals, conducting research by taking data in the field, processing and analyzing research data, writing research articles, and presenting. The research was done in the Department of Biology Universitas Negeri Surabaya (Unesa). The respondents were 31 biology students class of 2016 which are programming Animals Systematics and have written an article as the final report of project assignment from the field of practicum in Labuhan Mangrove Education Park Area, Bangkalan, Madura. Data were collected by using article assessment and questionnaire sheets. Data were analyzed descriptively. The results of this research showed Integration of scientific articles in systematic courses of animals to train scientific literacy in biology students was declared successful because the average value of articles produced by more than 75 and $75 \%$ of respondents was responded positively to this activity. Good article value and positive responses showed that students have met scientific literacy indicators.
\end{abstract}

Keywords - Scientific Article Writing, Animal Systematics Course, Scientific Literacy

\section{INTRODUCTION}

In the $21^{\text {st }}$ century, science will have a dramatic impact on the environment, on the quality of personal lives, and the world economy. Students must become scientifically literate and gather the notion of lifelong learning in science to prosper in this new century [1]. Reading, writing, and oral communication are critical literacy practices for students in a global society. In the context of scientific inquiry, literacy practices support students by sustaining them to deal with ideas, share their thoughts, enrich understanding, and solve problems [2]. Students must become scientifically literate in order to make informed decisions on important and illustrates issues; scientific literacy involves science knowledge and more [3].
In the last year of undergraduate study, some university often requires students to produce written reports or a scientific article, which contain suitable data collection, careful analysis in-depth discussion and new references. However, during the school year, there is a bit opportunity for the students to practice science writing; so they may lack the good skills to successfully complete the writing and achieve adequate writing quality [4]. Writing scientific articles is not easy for undergraduate students. This research was conducted in the Department of Biology, Universitas Negeri Surabaya with students which are programming Invertebrate Taxonomy as respondents revealed that students said that the most difficult part in article writing is writing discussion section [5]

This research was created more opportunities for college students which are to write in different courses and aspects that enable them to give organizing their ideas and understandings in a preferable way, so it can raise the writing quality is one of the solutions to this problem [6]. Students also must have the reading ability to evaluate the print-based information presented to them, and the writing ability to communicate their thoughts to others and have an impact on their thinking so they can to be scientifically literate [3]. The power for meaningful learning connecting with writing in communicative styles considers the limited power of creative writing for developing scientific understandings and recasts a description of scientific styles in light of modern classroom practices [7].

Reading and writing activities can serve as conceptual tools for helping students to interpret, analyze, and communicate scientific ideas. These activities can help follow in students' minds the complex reasoning and problem-solving processes that scientist's use in the course of their work [3]. The advantage of scientific writing seems best attributed to supplementary opportunities for students to talk about science, to critically evaluate the structure and quality of their arguments and evidence, and to state in their own words an obvious resolution to a biological issue [8].

This study was aimed to describe integration writing of scientific articles in systematic courses of animals to train scientific literacy in biology students. 


\section{METHOD}

The research was done in Department Biology, Universitas Negeri Surabaya (Unesa). This was a descriptive study. Biology students in Unesa need to get an opportunity to practice science writing; so they will get good skills to successfully complete the writing and achieve adequate writing quality and become scientifically literate. There are a lot of biological issues in the field of Animal Systematics which involve the study of invertebrate and vertebrate animals. Students who take Animal Systematics courses at Unesa are trained in scientific literacy skills through scientific writing activities. The indicators of scientific literacy that are expected of students are that they could deal with ideas, shared their thoughts, enriched their understanding, and could solve their problems. To realize the indicators, a series of scientific writing activities were carried out consisting of making research proposals, conducting research by taking data in the field, processing and analyzing research data, writing research articles, and presenting.

The respondents were 31 biology students class of 2016 programming Animals Systematics and wrote an article as a final report of project assignment from the field practicum in Labuhan Mangrove Education Park Area, Bangkalan, Madura. They were grouped into 11 groups and each group made research articles. The 11 scientific articles contained about animals invertebrate and vertebrate in the Labuhan Mangrove Education Park Area.

Data were collected by using article assessment sheets and questionnaire sheets. Article assessment sheets contained commonalities in scientific writing, in so much as most papers use similar category headings. The assessments rubric were Title, abstract, introduction, research methods, results and discussion, conclusion, references, writing system, good and true use of Indonesian language \& scientific name. There were maximal score if all of the components of assessment fulfil by students. The component of assessment described the fulfilment of scientific literacy in writing scientific articles. Questionnaire sheets contained a question about how scientific literacy training activities through scientific article writing gave impact to students.

Data were analyzed descriptively. Integration of scientific articles in systematic courses of animals to train scientific literacy in biology students was declared successful if the average value of articles produced by more than 75 and $75 \%$ of respondents responded positively to this activity. Good article grades and positive responses show that students have met scientific literacy indicators that are able to make initial ideas about animal systematic research in the field (proposals) share their thoughts about animal systematic research through writing scientific articles, enriching understanding of systematic material animals through field practicum activities, their research problems are solved by conducting data processing and data analysis accompanied by in-depth literature studies to produce a good scientific article.

\section{RESULTS AND DISCUSSION}

Students who take Animal Systematics courses at Unesa are trained in scientific literacy skills through scientific writing activities. The students had conducted a series of scientific writing activities consisting of making research proposals, conducting research by taking data in the field, processing and analyzing research data, writing research articles, presenting.

Students made a research proposal related to invertebrate and vertebrate animals in the Labuhan Mangrove Education Park Area, Bangkalan had been approved by their supervisor to conduct field practicum. From the field practicum in Labuhan Mangrove Education Park Area, Bangkalan, Madura, students wrote an article as a final report of project assignment from the field practicum. There were 11 scientific articles whose topics included discussing the diversity and potential of various animals both invertebrates and vertebrates. The articles discussed various animals such as arthropods (shrimp, crab), gastropods, echinoderms (sea stars), annelids, pisces (look fish), aves (bird), and bivalves (Table 1).

TABLE 1. ELEVEN ARTICLES FROM SCIENTIFIC WRITING ACTIVITIES TO TRAINED SCIENTIFIC LITERACY SKILLS

\begin{tabular}{|c|l|c|}
\hline No & \multicolumn{1}{|c|}{ Title } & Value \\
\hline 1 & $\begin{array}{l}\text { Diversity of Shrimp in The Labuhan Mangrove } \\
\text { Education Park Area, Bangkalan, Madura }\end{array}$ & $\mathbf{7 6 . 7}$ \\
\hline 2 & $\begin{array}{l}\text { Gastropoda Diversity in The Intertidal Zone of The } \\
\text { Labuhan Beach of Bangkalan Madura }\end{array}$ & $\mathbf{8 3}$ \\
\hline 3 & $\begin{array}{l}\text { The Diversity of The Sea Stars (Asternoidae) in The } \\
\text { Mangrove Land of Bangkalan Madura }\end{array}$ & $\mathbf{8 3 . 3}$ \\
\hline 4 & $\begin{array}{l}\text { Annelides Diversity in Mangrove Education Park, } \\
\text { Bangkalan, Madura }\end{array}$ & $\mathbf{8 0}$ \\
\hline 5 & $\begin{array}{l}\text { Diversity of Biola Crab (Uca Sp) in The Labuhan } \\
\text { Mangrove Education Park Area Bangkalan Madura }\end{array}$ & $\mathbf{8 6 . 7}$ \\
\hline 7 & $\begin{array}{l}\text { Potential of Gelodok Fish In Labuhan Mangrove } \\
\text { Madura East Java } \\
\text { Madential of Gastropoda In Labuhan Mangrove }\end{array}$ & $\mathbf{8 3}$ \\
\hline 8 & $\begin{array}{l}\text { Bird Diversity In Labuhan Mangrove Education Park } \\
\text { Madura Area }\end{array}$ & $\begin{array}{l}\text { Relationship Between Mercenaria mercenaria and } \\
\text { Gafrarium tumidum on Family veneridae in Labuhan } \\
\text { Mangrove Education Park Madura }\end{array}$ \\
\hline 10 & $\begin{array}{l}\text { Bivalvia Diversity in Labuhan Mangrove, Bangkalan } \\
\text { Madura }\end{array}$ & $\mathbf{7 6}$ \\
\hline 11 & $\begin{array}{l}\text { The Potential Of Crab In The Labuhan Mangrove } \\
\text { Madura East Java }\end{array}$ \\
\hline
\end{tabular}

The results obtained 11 articles have a value with an average 82.4 , and it showed that the average more than 75 which indicates that the article met the criteria of a good article. The assessment is carried out based on an assessment instrument developed to determine students' scientific literacy skills that are integrated into the activities of writing scientific articles (Table 2). Students were able to make initial ideas (proposals) about animal systematic research. They could share their thoughts about animal systematic research through writing scientific articles contained a title, abstract, introduction, research methods, results and discussion, conclusion, references, writing system, good and true use of Indonesian language \& scientific name. And then their research problems were solved by conducting data processing and data analysis accompanied by in-depth literature studies. The differences between proposal and final scientific articles were proposal just contained a title, abstract, introduction, research methods, references and then final scientific articles contained title, abstract, introduction, research methods, results and discussion, conclusion, references. 
TABLE 2. AN ASSESSMENT INSTRUMENT TO DETERMINE STUDENTS' SCIENTIFIC LITERACY SKILLS THAT ARE INTEGRATED with THE ACTIVITIES OF WRITING SCIENTIFIC ARTICLES

\begin{tabular}{|c|c|c|c|c|c|c|c|c|c|c|c|c|c|c|}
\hline \multirow[b]{2}{*}{ Score } & \multirow[b]{2}{*}{ Assessment rubric } & \multirow[b]{2}{*}{$\begin{array}{r}\text { Max } \\
\text { Score }\end{array}$} & \multicolumn{11}{|c|}{ article } & \multirow{2}{*}{$\begin{array}{c}\text { Everage } \\
\text { ( } \% \text { from } \\
\text { max } \\
\text { score) }\end{array}$} \\
\hline & & & 1 & 2 & 3 & 4 & 5 & 6 & 7 & 8 & 9 & 10 & 11 & \\
\hline & 1. TITLE & \multirow{5}{*}{4} & \multirow{5}{*}{3} & \multirow{5}{*}{4} & \multirow{5}{*}{4} & \multirow{5}{*}{4} & \multirow{5}{*}{4} & \multirow{5}{*}{4} & \multirow{5}{*}{4} & \multirow{5}{*}{4} & \multirow{5}{*}{4} & \multirow{5}{*}{4} & \multirow{5}{*}{4} & \multirow{5}{*}{$\begin{array}{c}3.9 \\
(98 \%)\end{array}$} \\
\hline 4 & $\begin{array}{l}\text { Communicative reflects the content, writing } \\
\text { correct, concise (10-15 words) }\end{array}$ & & & & & & & & & & & & & \\
\hline 3 & Only appropriate with the 3 criteria above & & & & & & & & & & & & & \\
\hline 2 & Only appropriate with the 2 criteria above & & & & & & & & & & & & & \\
\hline 1 & Only appropriate with the 1 criteria above & & & & & & & & & & & & & \\
\hline \multicolumn{2}{|r|}{ 2. $\quad$ ABSTRACT } & \multirow{5}{*}{4} & & & & & & & & & & & & \\
\hline 4 & $\begin{array}{l}\text { Concise; } \pm 250 \text { words; contains objectives, } \\
\text { methods, results and discussion; equipped } \\
\text { with keywords }\end{array}$ & & 3 & 3 & 3 & 3 & 2 & 4 & 3 & 4 & 2 & 2 & 3 & 2.9 \\
\hline 3 & Only appropriate with the 3 criteria above & & & & & & & & & & & & & \\
\hline 2 & Only appropriate with the 2 criteria above & & & & & & & & & & & & & \\
\hline 1 & Only appropriate with the 1 criteria above & & & & & & & & & & & & & \\
\hline & 3. INTRODUCTION & & & & & & & & & & & & & \\
\hline 4 & $\begin{array}{l}\text { Contains research conducted, why research } \\
\text { is carried out, research objectives, supported } \\
\text { by adequate literature }\end{array}$ & 4 & 3 & 3 & 3 & 3 & 3 & 3 & 3 & 3 & 3 & 2 & 3 & 2.9 \\
\hline 3 & Only appropriate with the 3 criteria above & & & & & & & & 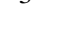 & & & & J & $(73 \%)$ \\
\hline 2 & Only appropriate with the 2 criteria above & & & & & & & & & & & & & \\
\hline 1 & Only appropriate with the 1 criteria above & & & & & & & & & & & & & \\
\hline & 4. RESEARCH METHODS & & & & & & & & & & & & & \\
\hline 4 & The method is clearly described & & & & & & & & & & & & & \\
\hline 3 & Only appropriate with the 3 criteria above & 4 & 3 & 3 & 3 & 3 & 4 & 3 & 3 & 4 & 3 & 3 & 3 & $\begin{array}{c}3.2 \\
(80 \%)\end{array}$ \\
\hline 2 & Only appropriate with the 2 criteria above & & & & & & & & & & & & & \\
\hline 1 & Only appropriate with the 1 criteria above & & & & & & & & & & & & & \\
\hline & 5. $\quad$ RESULTS AND DISCUSSION & & & & & & & & & & & & & \\
\hline 4 & $\begin{array}{l}\text { Data is presented in a concise, clear and } \\
\text { systematic analysis }\end{array}$ & & & & & & & & & & & & & \\
\hline 3 & Only appropriate with the 3 criteria above & 4 & 3 & 4 & 3 & 3 & 3 & 3 & 3 & 4 & 2 & 3 & 4 & $\begin{array}{l}5.2 \\
(80 \%)\end{array}$ \\
\hline 2 & Only appropriate with the 2 criteria above & & & & & & & & & & & & & \\
\hline 1 & Only appropriate with the 1 criteria above & & & & & & & & & & & & & \\
\hline & 6. $\quad$ CONCLUSION & & & & & & & & & & & & & \\
\hline 2 & $\begin{array}{l}\text { Concise, according to the purpose of the } \\
\text { study }\end{array}$ & 2 & 2 & 2 & 2 & 2 & 2 & 2 & 2 & 2 & 2 & 2 & 2 & $\begin{array}{c}2 \\
(100 \%)\end{array}$ \\
\hline 1 & Only appropriate with the 1 criteria above & & & & & & & & & & & & & \\
\hline & 7. REFERENCES & & & & & & & & & & & & & \\
\hline 3 & Complete writing & 3 & & & & 3 & & & & & & & & 2.4 \\
\hline 2 & Only appropriate with the 2 criteria above & 3 & 2 & 2 & 3 & 3 & 2 & 2 & 2 & 3 & 3 & 2 & 2 & $(80 \%)$ \\
\hline 1 & Only appropriate with the 1 criteria above & & & & & & & & & & & & & \\
\hline & $\begin{array}{ll}\text { 8. } & \text { WRITING SYSTEM } \\
\end{array}$ & & & & & & & & & & & & & \\
\hline 2 & $\begin{array}{l}\text { More than } 80 \% \text { according to the rules; } \\
\text { corrected according to advice }\end{array}$ & 2 & 2 & 1 & 2 & 2 & 2 & 2 & 2 & 2 & 2 & 1 & 2 & $\begin{array}{l}1.8 \\
(90 \%)\end{array}$ \\
\hline 1 & Only appropriate with the 1 criteria above & & & & & & & & & & & & & \\
\hline & $\begin{array}{c}9 . \\
\text { GOOD AND TRUE USE OF } \\
\text { INDONESIAN LANGUAGE \& } \\
\text { SCIENTIFIC NAME }\end{array}$ & & & & & & & & & & & & & \\
\hline 3 & $\begin{array}{l}90-100 \% \text { appropriate with Indonesian } \\
\text { language \& scientific name }\end{array}$ & 3 & 2 & 3 & 2 & 2 & 2 & 3 & 3 & 2 & 2 & 2 & 3 & 2.4 \\
\hline 2 & $\begin{array}{l}\text { 80-89\% appropriate with Indonesian } \\
\text { language \& scientific name }\end{array}$ & & & & & & & & & & & & & \\
\hline 1 & $\begin{array}{l}<80 \% \text { appropriate with Indonesian language } \\
\& \text { scientific name }\end{array}$ & & & & & & & & & & & & & \\
\hline Skor To & & 30 & 23 & $\begin{array}{l}2 \\
5 \\
\end{array}$ & 25 & 25 & 24 & 26 & 25 & 28 & 23 & 21 & 26 & $\begin{array}{c}24.7 \\
(82 \%)\end{array}$ \\
\hline Final ve & $\mathrm{e}=($ max score $:$ value obtained $) \times 100$ & 100 & $\begin{array}{c}76 . \\
7\end{array}$ & $\begin{array}{l}8 \\
3 . \\
3\end{array}$ & 83.3 & $\begin{array}{c}83 . \\
3\end{array}$ & 80 & $\begin{array}{c}86 . \\
7\end{array}$ & $\begin{array}{c}83 . \\
3\end{array}$ & $\begin{array}{c}93 . \\
3\end{array}$ & $\begin{array}{c}76 . \\
7\end{array}$ & 70 & $\begin{array}{c}86 . \\
7\end{array}$ & 82.4 \\
\hline
\end{tabular}


Based on the data of recapitulation of the article assessment instrument (Table 2), it is known that the article component consisting of title, research methods, results and discussion, conclusion, references, writing system, good and true use of Indonesian language \& scientific name has fulfilled more than $75 \%$ compliance with specified criteria. For Conclusion writing, $100 \%$ of respondents were able to get all the writing criteria. As for abstract writing an introduction, respondents still less than $75 \%$ got good writing criteria. Seven from nine assessment rubrics got good points it was mean students did scientific writing activities with well done and meaningful. Reading and writing activities can help students to understand science content in greater depth, focusing on concerned themes and ideas. Through reading and writing, students can construct upon their previous learning and make real-world relations. The skills of reading and writing can provide dynamic tools for learning science meaningfully [7]. Same like the result of research before, students got fewer points in the introduction. Most of the respondents argued that they got difficulties in linking their current research with prior research to show the state of the art of the research in their introduction [5].

The Rubric/instrument allows teachers to identify the skills students are achieving and skills that stay challenging. Such information is important if teaching is to be responsive to students' requires. Further, the Rubric illustrated that when criteria are incorporated in multiple courses over time, students' achievement will improve [10]. The teacher has taken an important first step to define what effective writing is and measuring the overall degree to which it has been achieved through the use of rubrics [11]

Students were also given a questionnaire to find out their response to the activities of integrating scientific article writing activities to improve their scientific literacy skills, there were 31 students who responded from the questionnaire. The respondents gave positive responses to scientific literacy training activities through scientific article writing (Table 3).

\section{TABLE $3 . \quad$ STUDENTS RESPONSE}

\begin{tabular}{|l|l|l|l|}
\hline No & \multicolumn{1}{|c|}{ Statement } & Yes (\%) & No (\%) \\
\hline 1 & $\begin{array}{l}\text { The student with preparing Animal } \\
\text { Systematics research proposals gave } \\
\text { benefit to Students }\end{array}$ & & \\
\hline 2 & $\begin{array}{l}\text { Assignments with preparing Animal } \\
\text { Systematics research proposals helped } \\
\text { students to learn the concept of Animal } \\
\text { Systematics }\end{array}$ & & \\
\hline 3 & $\begin{array}{l}\text { Fieldwork reports in the form of } \\
\text { scientific articles were beneficial for } \\
\text { students }\end{array}$ & $\begin{array}{l}\text { Writing field practice reports in the } \\
\text { form of scientific articles helped } \\
\text { students to understand the concept of } \\
\text { Animal Systematics }\end{array}$ & \\
\hline 5 & $\begin{array}{l}\text { Writing field practice reports in the } \\
\text { form of scientific articles improves } \\
\text { students' skills in scientific writing. }\end{array}$ & & \\
\hline 6 & $\begin{array}{l}\text { Writing a field practicum report in the } \\
\text { form of scientific articles provides } \\
\text { experience to students doing scientific } \\
\text { publications. }\end{array}$ & & \\
\hline
\end{tabular}

In general, based on Table 3, respondents gave a positive response to this activity. They are $100 \%$ agree that based on the response obtained it was known that assignments with preparing animal systematics research proposals gave benefit to students, writing field practice reports in the form of scientific articles improves students' skills in scientific writing and provides experience to students doing scientific publications.

From the questionnaire given to respondents, it was also known that they experienced difficulties when preparing and writing scientific articles (Figure 1).

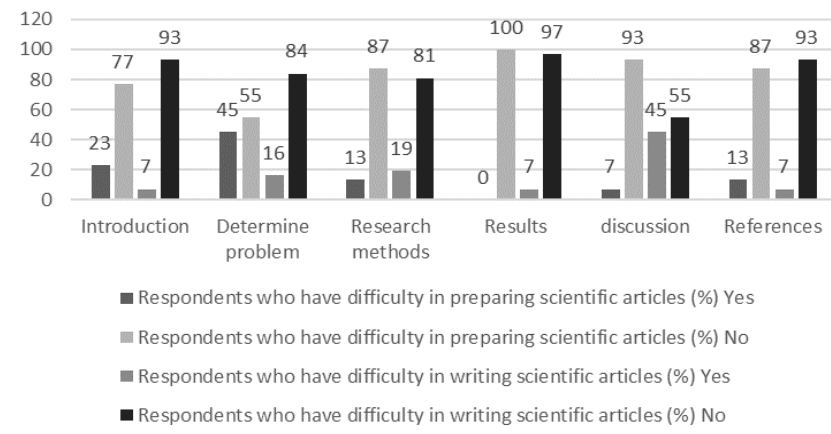

Fig 1. Difficulties of Students In Preparing And Writing Scientific Articles

Based on the table it is known that when preparing scientific articles, respondents experienced difficulties related to the introduction, determine problems, and references, but all three of these when writing scientific articles the number of respondents who experienced difficulties decreased. Most respondents had difficulty determining problems when preparing scientific articles. As for compiling results and discussions, not too many respondents experienced difficulties when preparing scientific articles but the number of those experiencing difficulties increased in number when they wrote an article, especially related to research method and the discussion. The common problems in student writing described above sometimes came from the lack of critical thinking process of abstracting and synthesizing complex material into a clear oral form seems to have positively influenced. Moreover, identifying a specific purpose, thesis, main points and essential evidence, and the clear movement of information essential to the oral genre translated into greater clarity in students' writing are in low skills [8].

Writing can play a potential role in the learning of science. Students with good writing skills are well on their way to achieving scientific literacy. The achievement of literacy also presupposes effective writing activities and strategies. When students write about their observations, manipulations, and findings, they examine what they have done in greater detail, they organize their thoughts better, and they sharpen their interpretations and arguments [1]. the students' increased writing self-efficacy connected with an enhanced quality of their written report. Therefore approaches that generate a perceived increased selfconfidence so it can lead students to improved results [12].

Students in the questionnaire also stated that lecturers played a very important role in this activity by guiding student work (98\% of respondents). They suggested for this 
lecture to be improved tutoring to students and adding time to work on articles. To better teaching for the next class, teachers can follow five instructional and curricular features that can support students in developing literacy in the context of science: (i) linking new ideas to prior knowledge and experiences (Connect science ideas with students' everyday experiences and with previous classroom experiences), (ii) anchoring learning in questions that are meaningful in the lives of students (Articulate questions that are meaningful and important to the lives of learners), (iii) connecting multiple representations (Explicitly reference visual elements in written text, and teach students to use graphics and text to support meaning-making), (iv) providing opportunities for students to use science ideas (Provide students with time, opportunities, and guidance to apply science learning to new contexts), and (v) supporting students' engagement with the discourses of science (Explicitly support scientific discourses, including the language of science and its practices). These five features will promote students' ability to read, write, and communicate about science so that they can engage in inquiry throughout their lives [2].

Science literacy underlines the centrality of communications skills and a commitment to informed and accessible contributions to the public over the uses of science. Writing tasks in science studies will need to provide opportunities for students to learn why and how they should purpose to meet these goals [9]. This research showed Integration of scientific articles in systematic courses of animals to train scientific literacy in biology students was declared successful because the average value of articles produced by more than 75 and $75 \%$ of respondents responded positively to this activity. Good article value and positive responses showed that students have met scientific literacy indicators. Students were able to make initial ideas (proposals) about animal systematic research in the field practicum in field practicum in Labuhan Mangrove Education Park Area, Bangkalan, Madura. Students could enrich understanding of systematic material animals from the class through field practicum activities. They could share their thoughts about animal systematic research through writing scientific articles contained a title, abstract, introduction, research methods, results and discussion, conclusion, references, writing system, good and true use of Indonesian language \& scientific name. And then their research problems were solved by conducting data processing and data analysis accompanied by in-depth literature studies to produce a good scientific article.

\section{CONCLUSION}

The conclusion of this study is that the integration of writing scientific articles in a systematic course of animals can be used to train scientific literacy in Unesa biology students. The suggestion based on the findings for future research are (i) linking new ideas to prior knowledge and experiences, (ii) anchoring learning in questions that are meaningful in the lives of students, (iii) connecting multiple representations, (iv) providing opportunities for students to use science ideas, and (v) supporting students' engagement with the discourses of science.

\section{REFERENCES}

[1] Glynn, S. M. \& Muth, K. D, "Reading and writing to learn Science: achieving scientific literacy", Journal of Research in Science Teaching, Vol. 31, No. 9, pp. 1057-1073, 1994.

[2] Krajcik, J. S. \& Sutherland, L. M, " Supporting students in developing literacy in Science", Science, vol. 328, no. 456; DOI: 10.1126/science.1182593, 2010

[3] Holliday, W.G., Yore, L.D., \& Alvermann, D.E, "The readingscience learning writing connection: breakthroughs, barriers, and promises", Journal of Research in Science Teaching, vol.31, pp.877-893, 1994.

[4] Venables, A., and Summit, R, 'Enhancing scientific essay writing using peer assessment', Innovations in Education and Teaching International, vol. 40, pp. 281-290, 2003.

[5] Ambarwati, R \& Faizah, U, 'Identifikasi kesulitan yang dihadapi mahasiswa biologi dalam penulisan artikel ilmiah" Prosiding Seminar Nasional Pendidikan Sains Tahun 2015.

[6] Prain, V, 'Learning from writing in secondary science: some theoretical and practical implications," International Journal of Science Education, vol.28, pp.179-201, 2016.

[7] Keys, C. W. "Revitalizing instruction in scientific genres: connecting knowledge production with writing to learn in Science", Sci Ed vol. 83 pp. 115-130, 1999.

[8] Curto, K. \& Bayer, T, 'Writing \& speaking to learn biology: an intersection of critical thinking and communication skills'. Bioscene, vol. 31, no. 4, 2005.

[9] Hand, B. Lawrence, C \& Yore, L. DA, 'Writing in science framework designed to enhance science literacy,' International Journal of Science Education, vol. 21, no. 10, pp. 1021-1035, 2006.

[10] Timmerman, B. E. C., Strickland, D. C., Johnson, R. L. \& Payne, J. R. ''Development of a 'universal' rubric for assessing undergraduates' scientific reasoning skills using scientific writing,', Assessment \& Evaluation in Higher Education, vol. 36, no. 5, pp. 509-547, 2011.

[11] Greenberg, K. P, 'Rubric use in formative assessment: a detailed behavioral rubric helps students improve their scientific writing skills", Teaching of Psychology 2015, vol. 42, no. 3, pp. 211-217, 2015.

[12] Tonissen, K. F., Lee, S. E., Woods, K. J., \& Osborne, S. A, "Development of scientific writing skills through activities embedded into biochemistry and molecular biology laboratory courses", International Journal of Innovation in Science and Mathematics Education, vol. 22, no. 4, pp. 1-14, 2014. 